\title{
ASPEK GRAMATIKAL NOVEL HUJAN KARYA TERE LIYE DAN RELEVANSINYA DALAM PEMBELAJARAN DI SEKOLAH MENENGAH ATAS
}

\author{
Aprilia Kurniawati, Suyitno, Slamet Mulyono \\ Universitas Sebelas Maret \\ apriliakur@gmail.com
}

\begin{abstract}
Abstrak: Tujuan penelitian ini adalah untuk mendeskripsikan (1)aspek gramatikal yang terdapat dalam novel Hujankarya Tere Liye dan (2) aspek gramatikaldalam novelHujankarya Tere Liye yang dapat dijadikan sebagai bahan pembelajaran di Sekolah Menengah Atas kelas XII. Penelitian ini termasuk penelitian kualitatif dengan sumber data utama adalah novel Hujankarya Tere Liye tahun 2017. Karakteristik novel Hujanyaitu sederhana, baik sederhana dalam penggunaan bahasa, dan sederhana dalam cerita yang disajikan. Teknik sampling penelitian ini menggunakan purposive sampling. Teknik analisis data yang digunakan adalah model analisis wacana sesuai dengan teks dan konteks. Hasil penelitian ini menunjukkan bahwa novel Hujan karya Tere Liye menggunakan aspek gramatikal yang tepat sehingga mampu membentuk sebuah wacana yang padu. Aspek gramatikal yang digunakan meliputi pengacuan (referensi), penyulihan (substitusi), pelesapan (elipsis) dan perangkaian (konjungsi). Wacana Hujan karya Tere Liye memiliki relevansi sebagai bahan ajar pembelajaran novel pada Sekolah Menengah Atas karena wacana ini disajikan dengan menggunakan bahasa yang sederhana dan menampilkan alur cerita yang ringan.
\end{abstract}

Kata Kunci :aspek gramatikal, bahan ajar, novel

\section{GRAMATIC ASPECTS OF HUJAN NOVELS BY TERE LIYE'S AND ITS RELEVANCE IN LEARNING AT SENIOR HIGH SCHOOL}

\begin{abstract}
The purpose of this study is to describe (1) the grammatical aspects contained in Tere Liye's novel "Rain" and (2) the grammatical aspect of Tere Liye's novel "Rain" which can be used as a learning material in High School XII class. This research includes qualitative research with the main data source is Tere Liye's novel "Rain" by 2017. The characteristic of the novel "Rain" is simple, both simple in the use of language, and simple in the story presented. Sampling technique of this research using purposive sampling. Data analysis technique used is discourse analysis model according to text and context. The results of this study indicate that Tere Liye's novel "Rain" uses the appropriate grammatical aspects so as to form a unified discourse. Grammatical aspects used include references, substitutions, ellipsis and conjunctions. The discourse of "Rain" by Tere Liye has relevance as a novel teaching material at High School because the discourse is presented in simple language and featuring a light storyline.
\end{abstract}

Keywords: grammatical aspects, teaching materials, novels

\section{PENDAHULUAN}

Bahasa merupakan sesuatuyang penting dalam hidup manusia. Komunikasi antara sesama manusia dapat terjadi karena keberadaan bahasa itu sendiri. Nababan (1992:66) mengungkapkan bahwa bahasa digunakan sebagai alat komunikasi untuk menyampaikan pesan atau maksud pembicara kepada pendengar. Sistem sosial dalam masyarakat berfungsi menentukan bentuk bahasa dan perkembangannya. Bahasa menjadi satu sistem dalam masyarakat selain sistem tradisi dan adat istiadat yang membentuk budaya manusia. Pada kehidupan seharihari bahasa tidak hanya berisi klausa dan kalimat, tetapi bahasa berisi teks.

Menurut Chaer (2011:1) bahasa adalah suatu sistem lambang yang berupa bunyi, bersifat arbriter digunakan oleh suatu masyarakat tutur untuk bekerja sama, berkomunikasi dan mengidentifikasi diri. 
Bahasa adalah alat komunikasi antara anggota masyarakat berupa simbol bunyi yang dihasilkan oleh alat ucap manusia.

Bahasa mempunyai peranan penting dalam komunikasi sehari-hari, salah satunya adalah sebagai alat komunikasi. Pernyataan yang penulis ungkapkan diperkuat oleh Soeparno (2002:5) bahwa fungsi umum bahasa adalah sebagai alat komunikasi sosial. Di dalam masyarakat ada komunikasi atau saling hubung antar anggota masyarakat. Oleh karena itu bahasa menjadi salah satu media yang paling penting dalam komunikasi, baik secara lisan maupun tulis.

Secara garis besar sarana komunikasi verbal dibedakan menjadi dua macam, yaitu sarana komunikasi yang berupa tulisan dan sarana komunikasi yang berupa bahasa lisan (Sumarlam, dkk 2003:1). Dalam konteks komunikasi tulis, Halliday(2009:17) mengungkapkan bahwa secara makro fungsi-fungsi bahasa terdiri dari 3 fungsi, yaitu fungsi ideasional, fungsi interpersonal, dan fungsi tekstual. Fungsi ideasional yaitu untuk membentuk, mempertahankan dan memperjelas hubungan di antara anggota masyarakat, fungsi ini berkaitan dengan peranan bahasa untuk mengungkapkan ide, gagasan dan isi pikiran serta untuk merefleksi realitas pengalaman partisipannya. Fungsi kedua yaitu fungsi interpersona, yaitu untuk menyampaikan informasi diantara masyarakat, fungsi ini berkaitan dengan peranan bahasa untuk membangun dan memelihara hubungan sosial. Fungsi ketiga, fungsi tekstual yaitu untuk menyediakan kerangka, perorganisasian dikursus yang relevan dengan situasi, fungsi ini berkaitan dengan peranan bahasa untuk membentuk berbagai mata rantai kebahasaan dan mata rantai unsur situasi yang memungkinkan digunakan bahasa tersebut sangat penting dalam kaitannya dengan analisis gramatikal.

Menurut Mulyasa

(2006)

menjelaskan bahan ajar atau materi pembelajaran (instructionalmaterials) secara garis besar terdiri dari pengetahuan, keterampilan, dan sikap yang harus dipelajari siswa dalam rangka mencapai standar kompetensi, dan sikap yang harus dipelajari siswa dalam rangka mencapai standar kompetensi yang telah ditentukan. Secara terperinci, jenis-jenis materi pembelajaran terdiri dari pengetahuan (fakta, konsep, prinsip, dan prosedur), keterampilan, dan sikap atau nilai. Bahan ajar memiliki fungsi strategis bagi proses pembelajaran yang dapat membantu guru dan siswa dalam kegiatan pembelajaran, sehingga guru tidak terlalu banyak menyajikan materi. Disamping itu, bahan ajar dapat menggantikan sebagian pesan guru dan mendukung pembelajaran individual. Hal ini akan memberi dampak positif bagi guru, karena sebagian waktu dapat dicurahkan untuk membimbing belajar siswa. Dampak positifnya bagi siswa, dapat mengurangi ketergantungan pada guru dan membiasakan belajar mandiri. Hal ini juga mendukung prinsip belajar sepanjang hayat (lifelongeducation).

Bahan pembelajaran dalam penyajiannya berupa deskripsi yakni berisi tentang fakta-fakta dan prinsip-prinsip, norma yakni berkaitan dengan aturan, nilai dan sikap, serta seperangkat tindakan/keterampilan motorik. Dengan demikian, bahan pembelajaran pada dasarnya berisi tentang pengetahuan, nilai, sikap, tindakan dan keterampilan yang berisi pesan, informasi, dan ilustrasi berupa fakta, konsep, prinsip, dan proses yang terkait dengan pokok bahasan tertentu yang diarahkan untuk mencapai tujuan pembelajaran.

Penelitian ini dapat dijadikan sebagai bahan pembelajaran di Sekolah Menengah Atas kelas XII, karena bahan pembelajaran ini disusun diluar lingkup materi kurikulum, tetapi memiliki keterkaitan yang erat dengan tujuan utamanya yaitu memberikan pendalaman dan pengayaan bagi siswa. Berkaitan dengan hal tersebut hasil penelitian ini nantinya dapat dijadikan sebagai bahan pembelajaran yaitu pada kompetensi dasar 
mengidentifikasi makna konotatif dan denotatif, gramatikal, kias dan lugas, makna referensial dan makna nonreferensial, makna umum dan khusus, perubahan, pergeseran makna kata, hubungan makna kata. Serta pada kompetensi dasar mengaplikasikan aspek kohesi dan koherensi pada tingkat paragraf sesuai yang tertera pada silabus mata pelajaran Bahasa Indonesia kelas XII. Jadi diharapkan hasil penelitian ini dapat dijadikan sebagai salah satu bahan pengajaran dalam mengajarkan materi ajar dalam dua kompetensi dasar tersebut.

\section{METODE PENELITIAN}

Penelitian ini merupakan penelitian yang menggunakan ancangan kualitatif. Penelitian kualitatif berusaha memahami makna dari fenomena, peristiwa dan kaitannya dengan orang-orang atau masyarakat yang teliti dalam konteks kehidupan ala situasi yang sebenarnya. Metode pengumpulan data dalam penelitian ini dilakukan dengan menggunakan metode baca catat dan kepustakaan.Prosedur penelitian yang dilakukan peneliti terdiri dari tahap klasifikasi data, deskripsi data, interpretasi data, dan simpulan. Metode analisis data dalam penelitian ini menggunakan analisis isi (content analysis). Teknik analisis isi mencakup upaya klasifikasi lambang yang dipakai dalam komunikasi menggunakan kriteria dan menggunakan teknik analisis tertentu dalam membuat prediksi (Bungin, 2012:84).

\section{HASIL DAN PEMBAHASAN}

Penelitian ini membahas aspek gramatikalyang terdapat pada novel Hujan yang dapat dîjadikan sebagai bahan pembelajaran di Sekolah Menengah Ataskelas XII. Dalam novel Hujan banyak terdapat pemarkah aspek gramatikal yang berfungsi mendukung kepaduan atau kekohesifan sebuah wacana. Penanda aspek gramatikal itu ialah: pengacuan (referensi), penyulihan (substittusi), pelesapan (ellipsis), serta perangkaian (konjungsi). Aspek gramatikal pada novel

Hujan dapat diuraikan sebagai berikut:

\section{Pengacuan (Referensi)}

Pengacuan adalah salah satu jenis kohesi gramatikal yang berupa satuan lingual tertentu yang mengacu pada satuan lingual lain yang mendahului atau mengikutinya. Pengacuan persona yang dipakai pada novel Hujankarya Tere Liye adalah pengacuan persona ketiga tunggal danpengacuan persona ketiga jamak.

\section{Pengacuan Persona Tunggal}

Berikut contoh data pada novel Hujan yang menggunakan pengacuan persona ketiga bentuk tunggal.

(1) Ibu akan ditanam dalam tanah dan dimakan semut. Begitu takutnya sehingga $a k u$ kadangmenangis tersedu-sedu karena imajinasikusendiri (Tere Liye, 2017: 10).

Data (1) pronomina persona tunggal $a k u$ mengacu pada unsur internal yangberada di dalam tuturan (teks) yang disebutkan sebelumnya, yaitu tokoh aku. Berdasarkan ciri-ciri yang disebutkan itu, $a k u(1)$ merupakan jeniskohesi gramatikal pengacuan endofora (karena acuannya berada di dalam teks) yang bersifat anafori s(karena acuannya disebutkan sebelumnya atau antesedennya berada di sebelah kiri) melalui satuan lingual berupa pronominapersona ketiga jamak bentuk bebas.

\section{Pengacuan Persona Jamak}

Berikutcontoh data pada novel
Hujan yang pengacuanpersona ketiga bentuk jamak.

(2) Karena itu aturan dalam pragraf diatas diterima saja. Masyarakat Indonesia cenderung spiritual. Mereka percaya akan adanya sesuatu di luar yang tampak (Tere Liye, 2017: 52).

Data (2) pronomina persona ketiga jamak mereka mengacu pada unsur lain yang berada di dalam tuturan (teks) yang 
disebutkan sebelumnya, yaitu masyarakat nusantara dan masyarakat Indonesia.

Berdasarkan ciri-ciri tersebut, mereka (2) merupakan jenis kohesi gramatikal pengacuan endofora (karena acuannya berada di dalam teks) yang bersifat anaforis (karena acuannya disebutkan sebelumnya atau antesedennya berada di sebelah kiri) melalui lingual berupa pronomina persona ketiga jamak bentuk bebas.

(3) Aku mengamati bahwa setidaknya dari enam keponakanku punya pertanyaan kritis tentang Tuhan dan agama. Apakah aku bisa mengharapkan setengah dari generasi muda Indonesia demikian? Gugatan-gugatan itu kadang muncul dalam celetukan. Dulu aku merasakan diam-diam seusia mereka (Tere Liye, 2017: 54).

Data (3) pronomina persona ketiga jamak mereka mengacu pada unsur lain yang berada di dalam tuturan (teks) yang disebutkan sebelumnya, yaitu keponakanku.

\section{Pengacuan Demonstratif Waktu (Temporal)}

Berikut uraian pengacuan démonstratif waktu yang lalu ditemukan pada novel Hujansebagai berikut.

(4) "Ya, kamu tahu, empat puluh dua tahun lalu, saat milinium baru, penduduk bumi hanya enam miliar. Sekarang? Tahun 2042? Sepuluh miliar. Kita hanya butuh empat puluh dua tahun saja." (Tere Liye, 2017: 11).

Pada data (4) terdapat pengacuan démonstratif waktu lampau. Kata empat puluh dua tahundan saat milinium barumengacu pada waktu sekarang yaitu saat sekarang ini ditulisnya tulisan tersebut oleh penulis, tulisan tersebut ditulis pada tahun 2042 sesuai dengan novel Hujan. Pengacuan tersebut termasuk jenis pengacuan eksolbra karena pengacuannya berada di luar teks. Pengacuan démonstratif waktu yang ditemukan pada novel Hujan sebagai berikut.

(5) "Dulu waktu masih kecil, Lail sering diajak ayahnya mengunjungi kerabat di kota lain.." (Tere Liye, 2017: 134).

(6) Detik itu....

Pada data (5) terdapat pengacuan démonstratif waktu lampau. Kata Dulu waktu masih kecilmengacu pada waktu lalu yaitu waktu itu menceritakan pada saat Lail kecil. Pengacuan démonstratif waktu yang ditemukan pada novel Hujan sebagai berikut.

(7) Tapi detik itu, sambil mengepalkan jemarinya, menatap Esok yang memeriksa khawatir seluruh sudut toko. Lail sungguh berdoa, semoga Esok selamat. (Tere Liye, 2017: 11). Pada data (6) terdapat pengacuan démonstratif waktu sekarang. Kata tapi detik itu mengacu pada waktu

sekarangatau pada saat kejadian. Berikut uraian pengacuan démonstratif waktu sekarang yang ditemukan pada novel Hujansebagai berikut.

(8) Berhari-hari kemudian, lebih banyak lagi korban yang ditemukan meninggal tanpa sempat menerima pertolongan. (Tere Liye, 2017: 41).

Pada data (7) terdapat pengacuan demonstratif waktu terdapat pada berharihari kemudian, kalimat tersebut mengacu pada saat akan datang pada kalimat berhari-hari kemudian diartikan sebagai hari setelah saat ini.

\section{Pengacuan Demonstratif Tempat (Lokasional) \\ Pengacuan demonstratif ini} mengacu pada tempat atau lokasi seperti contoh berikut:.

(9) Esok yang memeriksa khawatir seluruh sudut toko. Lail sungguh berdoa, semoga Esok selamat.(Tere Liye, 2017: 39)

Pada data (8) terdapat pengacuan démonstratif adalah sudut toko mengacu pada tempat atau lokasi yaitu pada bagian paling ujung dari toko. 


\section{Pengacuan Komparatif (Perbandingan)}

Dalam novel Hujan juga terdapat pengacuan komparatîf (perbandingan) yang bersifat membandingkan dua hal atau lebih yang mempunyai kemiripan atau kesamaan dari segi bentuk/wujud, sikap, sifat, watak, perilaku, dan sebagainya.Pengacuan komparatif juga ditemukan pada kalimat di bawah ini.

(10) Abu letusan gunung berapi purba yang telah menyebar jauh 24 jam terakhir telah tiba di kota mereka. Seperti cendawan raksasa, abu itu akan menutupi seluruh permukaan bumi dalam waktu beberapa hari ke depan. (Tere Liye, 2017: 44)

Pada data (9) satuan lingual $\underline{\mathrm{Abu}}$ letusan gunung berapi purba merupakan pengacuan komparatifyang berfungsi untuk membedakan nominal letusan gunung berapi purba dengan cendawan raksasa.

\section{Penyulihan (Substitusi)}

Penyulihan adalah jenis kohesi gramatikal yang berupa penggantian satuan lingualtertentu(yang telah disebut) dengan satuan lingual lain dalam wacana untuk memperoleh unsur pembeda. Yang meliputi substitusi nimonal, verbal, dan klausal.

Substitusi nominal, yaitu penggantian satuan lingual yang berkategori nominal(kata benda) dengan satuan lingual lain yang juga berkategori sama.

(11) Suhu rata-rata permukaan bumi turun drastis, hingga lima belas derajat Celsius selama sepuluh tahun yang baru berangsur normal ratusan tahun berikutnya. Itulah yang disebut vulcanic winter (Tere Liye, 2017: 49).

Pada data (10) satuan lingual nomina vulcanic winteryang telah disebut terdahulu digantikan oleh satuan lingual nomina pula yaitu kata suhu turun dengan drastis.

Substitusi verbal merupakan penggantian satuan lingual yang berkategori verbal(kata kerja) dengan satuan lingual lainnya yang juga berkategori verbal. Berikut ditemukan penggunaan substitusi verbal pada novel Hujan.

(12) "Kamu tahu, Lail, tidak ada kabar, yaitu kabar tidak ada kabar. Tidak ada kepastian juga adalah kepastian yaitu tidak ada kepastian." Maryam yang duduk di sebelahnya tertawa.(Tere Liye, 2017: 227)

Pada data (11) tampak adanya penggantian satuan lingual berkategori verbal tidak ada kabardengan satuan lingual lain yang berkategori sama yaitu kabar tidak ada kabar.Pada paragraf diatas juga ditemukan satuan lingual berkategori verbal yaitu tidak ada kepastian digantikan dengan satuan lingual lainnya yaitu sesuatu yang bersifat tidak pasti.

Substitusi klausal yaitu penggantian satuan lingual tertentu yang berupa klausa atau kalimat dengan satuan lingual lainnya yang berupa kata atau frase. Berikut substitusi klausal yang terdapat pada novel Hujan.

(13) Lail tidak mengerti. Wajahnya bingung. Esok memanggil Walikota dengan sebutan papa(Tere Liye, 2017: 98)

Pada data (12) terdapat substitusi klausal yaitu berupa satuan lingual kalimat itu disubstitusikan oleh satuan linguallain yang berupa Walikotadenganfrasa papa menggantikan kata walikota.

\section{Pelesapan(Elipsis)}

Pelesapan (elipsis) adalah pelesapan satuan lingual tertentu yang telah disebutkan sebelumnya. Unsur atau satuan yang dilesapkan dapat berupa kata, frasa, klausa, atau kalimat. Berikut pelesapan pada novel Hujan.

(14) Kedua belas petugas itu dipimpin satu orang superintendent, seorang ibu berusia lima puluh tahun. Tubuhnya besar, wajahnya galak, sangat disiplin. Lail dan teman-teman selantainya 
memanggil "ibu siri”.(Tere Liye, 2017: 80)

Pada data (13) terdapat pelesapan satuan lingual yang berupa frasa superintendent yang berfungsi sebagai subjek atau pelaku tindakan pada kalimattersebut. Subjek yang sama itu dilesapkan sebanyak dua kali yaitu dengan kata ibu siri.

\section{Perangkaian (Konjungsi)}

Perangkaian atau konjungsi adalah jenis kohesi gramatikal yang dilakukan dengan cara menghubungkan unsur yang satu dengan unsur yang lain dalam wacana.

(15) Rumah Lail lebih dulu, kemudian toko kue keluarga Esok. Hampir delapan kilometer menuju rumah Lail, kedua anak itu berjalan melewati kesedihan kota (Tere Liye, 2017: 37).

Pada wacana (14) ditemukan konjungsi kemudian yang juga merupakan ciri dari makna perangkaian dari urutan (sekuensial). Wacana ini mempunyai arti bahwa Lail akan mendatangi rumahnya setelah itu baru toko kue keluarga Esok.

(16) Esok dengan sabar membantu Lail melewati hambatan di jalan, memegangi tangannya saat memanjat reruntuhan, menjaganya, dan memastikan Lail baik-baik saja (Tere Liye, 2017: 37).

Pada wacana (15) ditemukan konjungsi kemudian yang juga merupakan ciri dari makna penghubung untuk menyertakan hubungan kata kerja dengan. Wacana ini mempunyai arti bahwa esok menyertakan Lail melewati jalan.

Selanjutnya juga ditemukan perangkaian (konjungsi) dan,Konjungsi dan pada data (37) berfungsi menghubungkan secara koordinatif antaraklausa yang berada disebelah kirinya dengan klausa yang mengandung kata danitu sendiri. Konjungsi dan pada kalimat tersebut menyatakan makna penambahan atau aditif.

(17) Telepon satelit bisa digunakan, selain handy talkie yang tidak membutuhkan jaringan (Tere Liye, 2017: 42).

Konjungsi selain pada data (16) berfungsi untuk menyatakan hubungan lain daripada atau hubungan kausal antarahandy talkie merupakan hubungan lain daripada telepon satelit

(18) Tidak ada awan disana, melainkan abu yang mengambang (Tere Liye, 2017: 45).

Konjungsi selain pada data (17) berfungsi sama dengan melainkan untuk menyatakan hubungan lain daripada, hubungan kausal pada wacana diatas antara awan dengan abu.

(19) "berikutnya maju !" petugas berseru. Dia tidak bisa berhenti melayani antrean karena tangisan Lail (Tere Liye, 2017: 46).

Konjungsi karena pada data (18) berfungsi untuk menyatakan hubungan sebab-akibat atau hubungan kausal antara klausa tidak bisa berhenti melayani antreansebagai sebab dengan klausa berikutnya yaitu tangisan Lailsebagai akibat.

(20) Gas itu menghalangi cahaya matahari yang menghangatkan bumi, membuat suhu rata-rata permukaan bumi turun drastis, hingga lima belas derajat Celsius selama sepuluh tahun.

Konjungsi hingga pada data (19), konjungsi hinggaberfungsi menyatakan batas terakhir (penghabisan). Klausa yang terakhir ialah lima belas derajat Celsius (merupakan batas terakhir suhu rata-rata permukaan bumi setelah gas menghalangi cahaya matahari).

(21) Namun, ia sedikit heran, jika bukan mengeluh karena sulit betul proses yang harus dilewati untuk dibaptis (Tere Liye, 2017: 14).

Konjungsi Namun pada data (20) berfungsi untuk menyatakan pertentangan antaraklausa.Konjungsi juga pada wacana (20) menyatakan makna penambahan (aditif), yaituberfungsi menghubungkan secara koordinatif antara klausa yang berada di sebelah kirinya dengan klausa 
yang mengandung kata juga itu sendiri atau klausa berikutnya. Konjungsi karena pada data (20) sekalipun berada pada awal kalimat tetapberfungsi untuk menyatakan hubungan sebab-akibat atau hubungan kausal antarakalimat sulit betul proses yang harus dilewati untuk dibaptissebagai akibat dengankalimat sebelumnya sebagai sebab.

(22) Masing-masing berbuat dari sepasang suku bunyi seperti bilik besar dan bilik kecil. Bunyi berasal dari sebuah jantung yang hidup di dalam rongga dada ibuku (Tere Liye, 2017: 14).

Konjungsi dan pada data (21) berfungsi menghubungkan secara koordinatif antaraklausa yang berada disebelah kirinya dengan klausa yang mengandung kata danitu sendiri. Konjungsi dan pada kalimat tersebut menyatakan makna penambahan atau aditif.

(23) Hal yang paling penting menakutkanku adalah ibu mati. Ketakutan itu kadang menyergap seketika. Kupikir rasa itu menyerang jika aku tidak sedang berada bersama ibu(Tere Liye, 2017: 20).

Konjungsi jika pada data (22) menyatakan makna syarat yang ditunjukkan padaklausa setelah konjungsi jika yaitu tidak sedang berada bersama ibu.Konjungsi jika pada data (22) menyatakan makna syarat yang ditunjukkan padaklausa setelah konjungsi jika disebutkan. Adapun konjungsi juga padanovel(24)menyatakan makna penambahan (aditif), yaitu berfungsi menghubungkan secara koordinatif antara klausa yang berada di sebelah kirinya dengan klausa yang mengandung kata itu sendiri atau klausa berikutnya.

(24) Bonefacius tidak berbohong. Ia bisa saja lupa satu dua detail, tetapi ia tidak menipu atau merancang khayalan (Tere Liye, 2017: 23).

Konjungsi tetapi berfungsi menyatakan hubungan pertentangan. Klausa yang dîpertentangkan ialah status inklusi lupa satu dua detail dengan tidak menipu atau merancang khayalan.

\section{Penerapan Aspek Gramatikal dijadikan sebagai Bahan Pembelajaran}

Sanjaya (2008) menjelaskan bahwa bahan atau materi kurikulum (curiculum material)adalahisiatau muatankurikulum yang harusdipahami oleh siswa dalam upaya mencapai tujuan kurikulum. Sungkono (2003: 11) mengatakan bahwa bahan ajar merupakan seperangkat bahan yang memuat materi atau isi pembelajaran yang"didesain" untuk mencapai tujuan pembelajaran. Terkait kompetensi berhubungan dengankurikulum diungkapkan dalam jurnal internasional sebagai berikut.

However, the skills necessary for successful academic enquiry complementhose required for effective practice. In particular, academic writing skills support effectiveprofessional communication and research skills allow for evidencebased practice. This paper describes the development of academic skills within a new undergraduate social work programme ata UK university, designed to meet the needs of a diverse and atypical student cohort. Havin grecognised the flaws in the early delivery of the programme, a revised curriculum has placed thedevelopment of academic research and writing skills at its core (Nathan Hughes, at all, 2011).

Jurnal tersebut menjelaskan pendidikan di Inggris mengharuskan penyelesaian akademik diperlukan kredit untuk gelar dengan praktik standar yang diperlukan dan kompetensi yang terkait dengan sebuah penghargaan profesional. Hal ini memerlukan yang menantang dan beragam program studi. Namun, keterampilan yang diperlukan untuk penyelidikan akademik bagimerekayang berhasil, mereka memerlukanlatihan efektif. Secara khusus, keterampilan menulis akademik 
mendukung efektif keterampilan komunikasi dan penelitianyang profesional memungkinkan untuk praktik berbasis bukti. Kelemahan dalam pengiriman awal program, kurikulum yang direvisi telah ditempatkan pengembangan penelitian dan menulis pada intinya.

Keterkaitan dengan penelitian ini, menurut Drs. Widodo Eko Rusmanto (guru bahasa Indonesia di SMA Negeri 4 Surakarta) menyatakan bahwa Novel Hujankarya Tere Liye ini dapat memenuhi Indikator Pencapaian Kompetensi, yaitu membantu siswa dalam memahami isi berita dan kemudian menyimpulkannya. Keterangan yang diberikan oleh Drs. Widodo Eko Rusmanto. disimpulkan bahwa Novel Hujankarya Tere Liye dapat dijadikan bahan ajar dalam pembelajaran teks novel kelas XII di Sekolah Menengah Atas, dapat membantu siswa dalam menyimpulkan isi teks novel sehingga dapat mencapai tujuan pembelajaran. Hal tersebut berdasarkan adanya unsur-unsur gramatikal yang mampu mempermudah siswa dalam memahami teks novel.

Novel Hujankarya Tere Liye selain mampu membantu siswa dalam mencapai tujuan pembelajaranyaitu mengevaluasi novel, melalui novel Hujankarya Tere Liye siswa juga mempelajari macam-macam konjungsi, keterangan waktu, tempat dan lain-lain dari novel. Novel ini juga dapat membantu siswa dalam memahami dan menyimpulkan maknanovel. Novel ini dinilai sesuai jika digunakan sebagai bahan ajar dalam pembelajaran novel di Sekolah Menengah Atas terutama siswa kelas XII kerena novel menggunakan gaya bahasa yang sederhana dan semi formal dalam penulisannya sehingga mudah dipahami oleh siswa.

Drs. Wdodo Eko Rusmanto. mengatakan tercapainya tujuan pembelajaran selalu ditunjang oleh bahan ajar yang sesuai dengan kebutuhan. Bahan ajar yang disediakan hendaknya sesuai dengan kebutuhan siswa, yaitu sesuai dengan tingkat berpikir, minat, latar belakang sosial budaya di mana siswa itu berada. Selain itu, bahan ajar hendaknya mampu meningkatkan proses pembelajaran menjadi lebih efektif dan interaktif (Belawati, 2003).

Penentuanbahan ajar yang baik, diperlukan proses pemilihan. Pemilihan prosesnya telah memenuhi 3 prinsip, yaitu: (1) Prinsip relevansi: materi hendaknya berkaitan erat dengan pencapaian standar kompetensi dan kompetensi dasar; (2) Prinsip konsistensi: jika kompetensi dasar yang harus dikuasai oleh siswa ada empat macam, maka bahan ajar yang harus diajarkan juga mencakupi empat macam tersebut; dan (3) Prinsip kecukupan: materi yang diajarkan hendaknya cukup memadai dalam upaya membantu siswa menguasai kompetensi dasar yang diajarkan(Belawati, 2003).

Pembelajaran di kelas tidak akan lepas dari bahan ajar. Bahan ajar yang relevan sangat dibutuhkan siswa sebagai sarana untuk mencapai tujuan pembelajaran. Novel Hujankarya Tere Liye dapat digunakan dan dikembangkan sebagai bahan ajar mata pelajaran bahasa Indonesia di SMA kelas XII. Novel Hujankarya Tere Liyedapat memenuhi tujuan pembelajaran, disesuaikan dengan kebutuhan siswa, memiliki gaya penulisan yang sederhana sehingga mudah dipahami, serta bukan merupakan berita serius (dangkal).

\section{SIMPULAN}

Aspek gramatikal yang ditemukan pada novelHujandiantaranya referensi pronomina persona (persona ketiga jamak bentuk bebas dan persona ketiga jamak bentuk terikat), referensi demonstratif (demonstratif waktu dan tempat), dan referensi komparatif. Kemudian ditemukan pula penggunaan substitusi nominal, substitusi verbal, substitusi frasal, dan substitusi klausal. Selain itu ditemukan pula penggunaan elipsis serta konjungsi pada novel Hujankarya Tere Liye.

Aspek gramatikal yang dapat dijadikan sebagai bahan pembelajaran di Sekolah Menengah Atas kelas XII, guru 
dapatmenjadikan hasil penelitian ini sebagai bahan pembelajaran pada kompetensi dasar"Mengidentifikasi makna konotatif dan denotatif, gramatikal, kias dan lugas, makna referensial dan makna nonreferensial, makna umum dan khusus, perubahan, pergeseran makna kata, dan hubungan makna katakhususnya pada pembelajaran relasi makna", serta pada kompetensi dasar "Mengaplikasikan aspek kohesi dan koherensi pada tingkat paragraf" yaitu pada aspek gramatikal yang berupa pengacuan (referensi) dan perangkaian (konjungsi).

\section{REFERENSI}

Belawati, Tien. 2003. Pengembangan Bahasa Ajar. Jakarta: Pusat Penerbitan UT.

Bungin. 2012.Tata Bahasa Baku Bahasa Indonesia. Jakarta: Balai Pustaka.

Chaer, Abdul. 2011.Linguistik Umum. Jakarta: Rineka Cipta.

Halliday.2009. Critical Discouse Analysis of Reporting on "Sawerang for Building KPK" in Media Indonesia Daily Newspaper. Volume 5. Hal. 213-224.

Mulyasa. 2006. Kajian Wacana: Teori, Metode dan Aplikasi Prinsip-Prinsip
Berdasarkan simpulan di atas, hasil penelitian ini diharapkan agar para penulis novel memperhatikan aspek-aspek gramatikal yang digunakan dalam novel untuk dapat menghasilkan kepaduan dalam sebuah wacana. Selain itu, hasil penelitian ini diharapkan dapat dimanfaatkan oleh guru sebagai bahan pembelajaran untuk mengajarkan materi pembelajaran yang berkaitan dengan aspek gramatikal pada novel maupun materi pembelajaran mengenai kepaduan paragraf.

Analisis Wacana. Yogyakarta: Tiara Wacana.

Nababah. 1992.Pengajaran Wacana. Bandung: Angkasa.

Sanjaya. 2008. Teori dan Praktik Analisis Wacana. Surakarta: Pustaka Cakra.

Soeparno. 2002. Analisis

Wacana. Bandung: Pakar Raya.

Sumarlam, dkk. 2003. Teori dan Praktik Analisis Wacana. Surakarta: Pustaka Cakra.

Sungkono. 2003. Strategi Belajar Mengajar. Bandung: Pustaka Setia. 